\title{
Factors Influencing Readiness for Transformational E-Government: An Empirical Study on Perspective of Local Governments in South Africa
}

\begin{abstract}
FETNANI CECILIA
ABSTRACT

The purpose of the chapter is to explore the readiness of local governments (municipalities) in South Africa to transform to be able to deliver services to its citizens using ICT. The study applied Structuration Theory (ST) and drew on the concepts of duality of structure and action particularly: the enactment of technology-in-practice (ETiP) as a lens to understand and interpret the social construct. The objective was to determine the factors contributing to the readiness of municipalities to adopt ICT to transform the way and manner they deliver essential services to the public. The concept "Transformational e-Government" $(\mathrm{TeG})$ is discussed in this chapter to analyse the determinant factors influencing service delivery. This chapter aimed to analyse the readiness of South African local government when rendering services through information and communication technology (ICT). An interpretive case study methodology where semi-structured interviews were used to collect information. The findings were that out of the 15 participated municipalities only $7 \%$ were ready for TeG initiatives, $60 \%$ were near ready and $33 \%$ have a long way to go to implement TeG initiatives. The results also showed that 5 out of the 8 Metro Cities in South Africa were ready to implement TeG initiatives successfully. The implications of the study were that, the ST is able to provide the lens through which to understand, interpret and determine the factors contributing to the readiness of municipalities to implement TeG to improve service delivery.
\end{abstract}

Keywords: Factors influencing; e-government; Information and Communication Technology (ICT).

\section{INTRODUCTION}

E-Government gained significant popularity in developing counties at the beginning of the 21st Century. These were seen from the many governments' websites, e-services and other electronic transformation initiatives and strategies. However, these initiatives and strategies in relation to the municipalities studied did not produce the desire results. Dada (2006) in his article "The failure of egovernment in developing countries: a literature review" alluded to this observation. Furthermore, Heeks (2004) indicates that $35 \%$ of e-government projects in developing countries resulted in total failures and that $50 \%$ were partial failures. To improve productivity, Irani, Rudd, Gallo, Ricketts, Friedel, and Rhoades (2007) suggest that application of the Transformational e-Government (TeG) to address the cultural and organisational barriers which have hindered the realisation of service delivery in the local government spheres. Irani et al. (op.cit.) defined TeG as "the exploitation of e-government such that benefits can be realized" i.e., the use of computer-based information and communications technologies (ICT) to enable radical improvement to the delivery of services. Although there has not been much literature in this area of the phenomenon, literature reviewed thus far indicates that there are challenges which have hampered many municipalities in achieving improved service delivery through their technology investments.

The South Africa Constitution (Act 108 of 1996) provides for a three-tier government system: National Government, Provincial Governments and Local Governments (Municipalities). The provincial governments are the nine (9) main regions of South Africa and each region has a number of Municipalities of various types; about 278 in total across South Africa. The constitution mandates municipalities to deliver services to the citizens in their jurisdiction, with powers to raise revenue and to receive transfers from provincial and national governments i.e., service delivery accountability. 
This chapter presents a preliminary understanding and interpretation of a real case study of challenges of TeG drawing on the concepts of duality of structures (DoS) from Structuration Theory (ST). The study drew on Orlikowski's (2000) socio-technical analysis of Gidden's DoS and in particular "enactment of technologies-in-practice" (ETiP) (see Fig. 1) as a lens through which to determine the factors contributing to the readiness of Municipalities to implement TeG. The chapter presents a theoretical understanding and interprets the concept associated with the point of view of using information from a real case study. The chapter also suggests a general framework that provides insight to the degree of readiness of Municipalities to adequately implement TeG initiatives and strategies. Given the above, this Chapter is structured as:

(a) A brief overview of Structuration Theory and the concept of enactment of technology-inpractice (ETiP) used in the analysis of the case study;

(b) A summary of the methodology and the case narrative;

(c) Reinterpretation of the case study from the perspective of (ETiP); and

(d) Implications as a general framework;

\section{UNDERPINNING THEORY: OVERVIEW OF STRUCTURATION THEORY}

This overview will first trace the various attempts that have been made in literature to "reconcile" Structuration Theory (ST) with the very real challenge of gaining a deeper understanding of the challenge. The impact of eGovernment strategies and the factors influencing the implementation of TeG is also described. Twum-Darko (2011: 48-49) commented that ST allows for TeG to be seen as a structure. In order to deepen the understanding of ST and how it is applied in the field of technology innovations which is relevant to this study, one need to understand Giddens' (1984:9-14) characterisation of sociological enquiry, specifically of agency and structure as described in this section.

Agency/Agent and Structure are two of the central constructs of Structuration Theory. Giddens (1984:14) argues that human agency is the 'capacity to make a difference' (also known as 'transformative capacity') i.e., the flow or pattern of people's action and not people's intentions of doing things. Giddens $(1984: 17,377)$ further describes structure as resources and guidelines frequently implicated in the ETiP. According to Giddens (ibid.) guidelines are techniques used in the enactment of social practices. Therefore, on-going use of technology strengthens technology-inpractice and therefore becoming repeatedly used to carry out social life's demands. Hence deducing from Giddens (ibid.) 'rules and resources' are recursively implicated in the reproduction of social systems. Thus, structure is what gives form and shape to social life, but it is not itself the form and shape (ibid). Structure exists only in and through the activities of human agents (Giddens \& Pierson, 1989:256). Walsham (1993:34) describes action as having strongly routinized aspects which is both conditioned by existing cultural structures and also creates and recreates those structures through the enactment process. By theorizing this social system, Giddens (ibid.) urged for a conceptualization of the contextuality of duality of structure and hence argued that "the constitution of agents and structure are not two independently given sets of phenomena, a dualism, but represent a duality." Thus, duality in ST refers to the way in which action and structure presupposes each other. Giddens (ibid.) further argues that "the structural properties of social systems are both medium and outcome of the practices they recursively organise." The latter is what this chapter intends to address.

Drawing on Giddens' argument, Twum-Darko (2011:48-49) further argues that ST offers us the window through which to analyse the structure and its formulation (action) as one that constitute a duality i.e., the structural characteristics affect the action, and in turn, the structure can be modified through action which results in a new structure that is the basis of the next change. Barley (1990) further argues that 'technically-driven social change is likely to be rooted in a technology's material constraints' (here structure ('constraints') and agency ('driven') are conflated), but that these must be transformed into social forces if technology is to have a significant effect on social organization. Furthermore, Orlikowski's structurational model of the 'duality of technology' (Orlikowski, 1992) goes somewhat further in explicitly introducing material technology into the structure/agency duality, and also suggesting that social rules may be 'embedded' in information technology solutions during their design, but insisting that they cannot be programmatically read off by humans in a determinist manner (interpretive flexibility) which is outside the scope of this chapter. 
Orlikowski (2000:407) used ETiP (see Fig. 1) to further elaborate on the two notions of emergent structures and enactment, Orlikowski indicated that structures are embodied in technologies to be appropriated by users (municipalities); while users (municipalities) may appropriate these differently from time to time; thus the notion "to constitute, actuate, and perform". "That is, rather than starting with the technology and examining how actors appropriate its embodied structures, this view starts with human (municipalities) action and examines how it enacts emergent structures through recurrent interaction with the technologies at hand" (op.cit.).

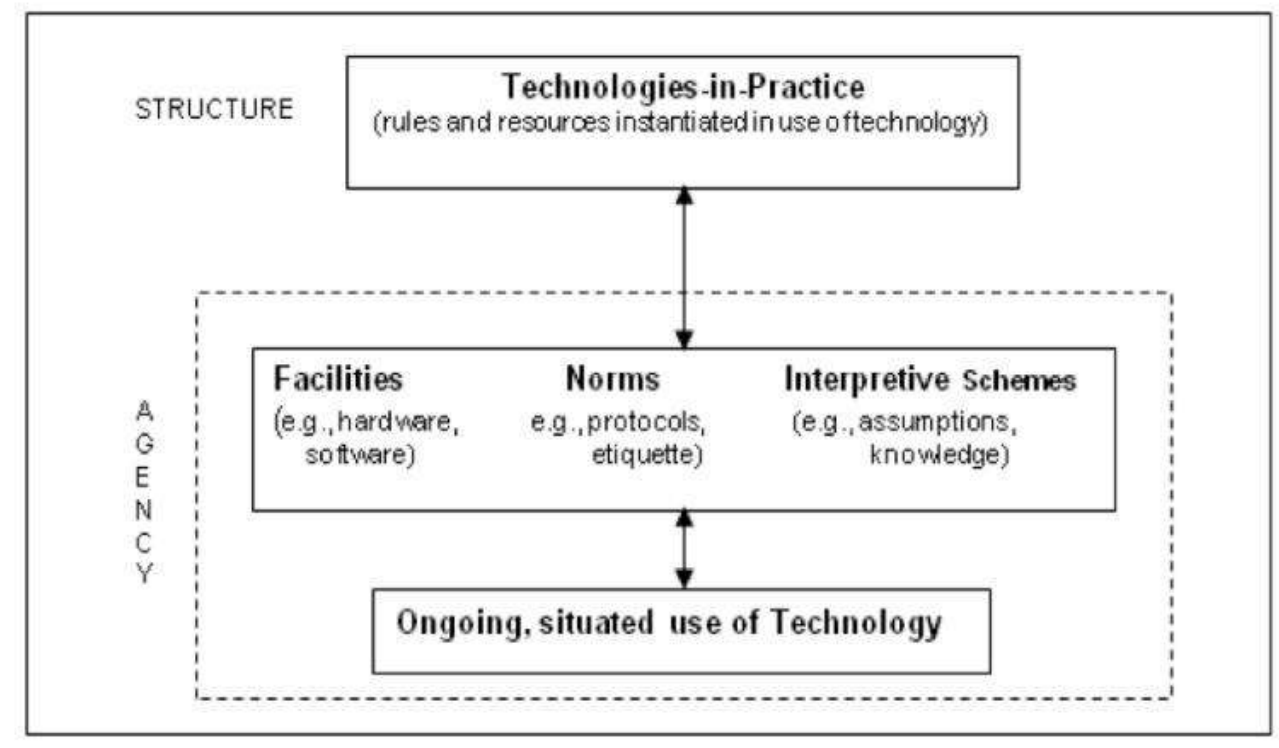

Fig. 1. Enactment of technology-in-practice

[Source: Orlikowski (2000)]

Therefore, this structurational model (Fig. 1) which is based on Giddens' model represents Orlikowski's argument of technology appropriation. To further elaborate on Orlikowski's concise description of the structurational model, it is repeated verbatim: "When people (municipalities) use a technology, they draw on the properties comprising the technological artefact - those provided by its constituent materiality, those inscribed by the designers, and those added on by users through previous interactions (e.g., specific data content, customized features, or expanded software/hardware accessories). People (municipalities) also draw on their skills, power, knowledge, assumptions, and expectations about the technologies and its use, influenced typically by training, communication, and previous experiences. These include the meanings and attachments - emotional and intellectual - that users (municipalities) associate with particular technologies and their uses, shaped by their experiences with various technologies and their participation in a range of social and political communities. Users (municipalities) also draw on their knowledge and experiences with the institutional contexts in which they live and work, and the social and cultural conventions associated with participating in such contexts." [Orlikowski, 2000:410].

\section{THE CASE STUDY}

\subsection{Methodology}

Interpretive case study methodology (Walsham, 1995) was used to guide the collection and analysis of data. The underlying objective of this approach is to understand and interpret the social phenomenon, i.e., transformational eGovernment and also to have a deeper understanding of this complex social reality in the light of the inherent influences and constraints of information technology solutions. Adapting the concepts of technology-in-practice of ST, a theoretical understanding was developed which enabled a comprehensive interpretation of the results in terms of the contributions made by the inclusion and use of technology to institutionalise the factors contributing to the 
readiness of the organisation. Information collected included documentations such as Technology Infrastructure Policies, Corporate Governance Policy, Enterprise Architecture Strategy, Human Resources Policies, Legal Frameworks, Project Management principles and conducting unstructured interviews with staff of two (2) Metro Cities and fifteen (15) Municipalities at Senior, Middle management and clerical staff who have participated in or have implemented eGovernment initiatives to transform services delivery infrastructure. Most of the interviews lasted between one and half to two hours and they were all fully taped and transcribed.

\subsection{Overview of the Case}

The South African Constitution (Act 108 of 1996) empowers Provincial Governments to have the oversight role over Local Governments (Municipalities). They also have exclusive powers of the National Government and concurrent powers as the National Government. The National Government has the mandate to formulate policies and regulations, an oversight role of both Provincial and Local Government and has major taxing powers. In terms of the Municipal Systems Act 32 of 2000, Municipalities are accorded the core principles, mechanisms and processes that are necessary to enable municipalities to move progressively towards the social and economic upliftment of local communities, and ensure universal access to essential services that are affordable to all. The Act also mandate municipalities to empower the poor and ensure that they put in place service tariffs and credit control policies that take their needs into account by providing a framework for the provision of services, service delivery agreements and municipal service districts

They are to establish a framework for support, monitoring and set standard with other spheres of government in order to progressively build local government into an efficient, frontline development agency capable of integrating the activities of all spheres of government for the overall social and economic upliftment of communities in harmony with their local natural environment. These mandates are distinctive in that each sphere has its own unique area of operation. The mandates are also interdependent which means that the three spheres are required to co-operate and acknowledge respective areas of jurisdiction and at the same time the constitutional mandates are interrelated ensuring that there is a system of cooperative governance and intergovernmental relations among the three spheres (section 40 of the South African Constitution, Act 108 of 1996). There are 278 municipalities in South Africa i.e., 8 Metros, 44 District Municipalities and 226 Local Municipalities.

\subsection{Unit of Analysis}

Given Table 1; 17 Municipalities: 9 Local municipalities - one from each Province, 6 District municipalities - one from each Province except Western Cape, Kwazulu-Natal, and Gauteng provinces and 2 Metros (Johannesburg and Tshwane) were interviewed. A total of 85 personnel across the 17 Municipalities participated in the interviews (Table 1: Field Work). The outcome is tabulated in Table 2 of Appendix A.

Table 1. Field work

\begin{tabular}{lllllll}
\hline \multicolumn{2}{c}{ Municipality } & \multicolumn{5}{c}{ Number of participants } \\
\hline Type & Number & Chief director & Director & IT Manager & IT technician & Total \\
\hline Metros & 2 & 2 & 4 & 6 & 6 & 18 \\
District & 6 & 6 & 6 & 6 & 12 & 30 \\
Local & 9 & 9 & 9 & 9 & 10 & 37 \\
Total & 17 & 17 & 19 & 21 & 28 & 85 \\
\hline
\end{tabular}

\section{ENACTING TRANSFORMATIONAL E-GOVERNMENT IN PRACTICE}

\subsection{Readiness Assessment}


Transformation e-Government (TeG) initiatives at municipalities was considered as a process of ETiP i.e., transforming (re-inventing processes and different channels) public services using ICT. The need for TeG was initially proposed by the Ministry and Department of Provincial and Local Government (dlpg, 2007:2) as a mandate from the January 2007 Extended Cabinet Lekgotla. Therefore, the analysis started with the identification of the pre-condition for TeG success in municipalities. It was therefore assumed that protecting and enhancing the lives of citizens via ICT capabilities i.e., high performance in service delivery is a major ETiP pursued by the management of municipalities. The ETiP (Orlikowski, 2000) was traced in the context of TeG at municipalities which participated in the study (see Table 1: Appendix A). The factors that prevented sufficient implementation of TeG across the municipalities were considered. Drawing from the information gathered from the participated municipalities (see Table 3: Appendix B) this consideration represents, fairly, the situation at the remaining 263 municipalities in South Africa. Given Tables 2 and 3 (see Appendices A and B) in relation to the participated 15 municipalities, only $7 \%$ are ready for TeG initiatives, $60 \%$ are near ready and $33 \%$ have a long way to go to implement TeG initiatives. There are only 5 out of 8 Metro Cities in South Africa which participated (Table 3) appeared ready to implement TeG initiatives successfully. These factors fall into 3 broad categories as follows:

\subsubsection{Facilities}

- Unaligned business processes and limited integration of systems;

- Physical presence of citizens required at Municipal offices for basic transactions and service queries;

- Limited payment options for services delivered;

- Paper-based filing systems and extensive manual processes;

\subsubsection{Norm}

- Absence of eGovernment champions and inadequate ICT leadership;

- Lack of coherent strategy for ICT for service delivery;

- Non-aligned governance structures impacting on ICT decisions

- Lack of formalized reporting and management information system;

- The new legislation promulgated to ensure improved service delivery inadequately implemented e.g., Municipal property rates Act, 2004;

\subsubsection{Interpretive scheme}

- Nepotism and favouritism in service delivery due to;

- Inadequate knowledge;

- Bad judgment to rollout service types;

- Poor data recording of service types and for which community;

- Limited access points to obtain services or query services delivered and long queues?

\subsection{Transformational E-Government}

Municipalities (District and Local Councils) and Metro cities are like any organization whose main mandate is to deliver basic services to the public. As such are to extent driven by ICT enabled organizational transformation initiative like TeG. Therefore, the readiness of these organizations to implement TeG initiatives can be studied using the concepts of ETiP which is derived from duality of structure: a perspective of Structuration Theory as a lens through which to understand and interpret the factors impacting on TeG initiatives in organizations. It further demonstrates that TeG can be studied using technological determinism, social construction of technology perspective as argued by Twum-Darko (2011:46-50). The outcome of the study suggests that concept of "Scaling" would be appropriate to address the challenges of TeG initiatives highlighted in this chapter. According to Sahay and Walsham (2005:43), "Scaling" is the processes and embedded practices by which heterogeneous networks around a technology (or TeG) are spread, enhanced, scoped, and enlarged. 
The implication is that scaling deals with aspects of geography, software architecture, people, processes, infrastructure, technical support, and political support.

In the context of TeG, scaling will imply the improvement of the pre-condition criteria from an indicator of 2 or 3 to 4 or 5 i.e., from not ready to ready. In other words, as argued by Twum-Darko (2011:202203) scaling is the process of taking what is "global" into a "local" framework that ensures that local consensus and conditions are considered, i.e., "glocalization" (Robertson, 1992; Rolland and Monteiro, 2002). As such "scaling" TeG may not work for the well-resourced and well-developed Metros in South Africa (e.g., the City of Johannesburg, the City of Tshwane and Ekurhuleni in Gauteng, City of Cape Town and eThekwini in Kwazulu-Natal). These Metros are ready for TeG initiatives. However, "scaling" would be suitable for the less resourced and less developed municipalities which are looking up to national government and their Provinces for capability and capacity support. This presupposes that each Province (global) may have to decide to have a centralized system of core "global" functionalities that is uniform across the province for the less developed and resourced municipalities but with "local" customizations that allow for local requirements and expectations.

\section{CONCLUSION}

\subsection{Contribution}

The theoretical contribution of the chapter is the application of the concept of enactment of technologies-in-practice (ETiP) of Giddens' duality of structures as a lens through which socially constructed phenomena such as ICT for development can be studied. It encapsulates the entire study effort, but more than that, could serve as a guideline for the implementation of TeG initiatives to improve the delivery of essential services by Governments. One is therefore not saying that applying the concept of ETiP would guarantee successful implementation of TeG, but expects that the likelihood of success would increase. Methodologically, the study adopted an interpretive approach based on multiple case studies where semi-structured interviews were used to collect information. ETiP was further used to guide the analysis and interpretation of information collected from conceptualization to implementation and support of TeG initiatives. The contribution therefore is the way in which the concept of ETiP was applied to study the socio-technical processes in the case studies of TeG. It is submitted that this could serve as an example to other researchers involved in similar projects. The experience indicated that it is captivating in ICT for development study to use underpinning theories instead of just relying on literature, although, these underpinning theories do not come with a method of how to make use of them. The practical contribution is a normative approach which could inform the process of the TeG initiative from conceptualization to its implementation and subsequent support. The review of the available literature showed a dearth of researched frameworks and theories that could facilitate this process - especially as far as TeG initiatives processes are concerned. It is hoped that this study goes some way towards addressing this limitation. It must be emphasised that the normative application of ETiP cannot and will not guarantee success, but it is expected that its use as a lens would increase the likelihood of success. Another practical contribution is the detailed insight provided by the case study which revealed that TeG initiatives in developing economies should be linked to productive activities of municipalities by understanding the social context of work, tasks and the municipality. This will then help increase the social integration of technology initiative and, hopefully, its institutionalization.

\subsection{Recommendation for Future Study}

There are a number of limitations to this study which have implications for further study. One limitation is related to the fact that there is very little application of ETiP as a lens to study challenges impacting on eGovernment related projects in Africa. While this study has provided a general view of degree of readiness by 15 municipalities to undertake TeG initiatives successfully, it requires further study to validate it with more municipalities. A second limitation is related to the transferability of the results into other contexts or countries. Since the study took place in South Africa, within a set of particular challenges, the methodology and the lessons learnt cannot just be transferred or replicated. Rather, in 
using such a normative approach there should be allowances for flexible thinking and action such that challenges or the unexpected can be identified and incorporated into the guidelines. The application of the proposed frameworks may need various levels. A third limitation of this study is that ETiP was applied in retrospect. It would be useful to have followed or observe the conceptualization and implementation of TeG in these municipalities and how the interplay between the structure and agency were mediated. Finally, a limitation, perhaps applicable to most studies involving service delivery transformation, is that transformation or reform in them is an ongoing process. The study was conducted before the 2014 national elections and there was no indication that the TeG initiatives would stop or modification would not be introduced to the processes. There will continue to be capacity and skills problems, organizational reform, and re-ordering of power structures within the municipalities which could create a different picture. Continuous development of the proposed normative approach and possibly minor adjustments to the use of ETiP as a lens may be necessary to increase the likelihood of deeper understanding and interpretation of factors affecting TeG initiatives in municipalities.

\section{REFERENCES}

Setiawan, Adib Rifqi. (2017, February 24). Penerapan Pendekatan Saintifik untuk Melatihkan Literasi Saintifik dalam Domain Kompetensi pada Topik Gerak Lurus di Sekolah Menengah Pertama. Undergraduate Thesis. Bandung: Universitas Pendidikan Indonesia. URL: http://repository.upi.edu/29074/

Setiawan, Adib Rifqi. (2020, April 21). Lembar Kegiatan Literasi Saintifik untuk Pembelajaran Jarak Jauh Topik Penyakit Coronavirus 2019 (COVID-19). Edukatif: Jurnal Ilmu Pendidikan, 02(01): 28-37. DOI: https://doi.org/10.31004/edukatif.v2i1.80

Setiawan, Adib Rifqi. (2020, March 01). Pendidikan Literasi Finansial Melalui Pembelajaran Fiqh Mu'āmalāt Berbasis Kitab Kuning. Nazhruna: Jurnal Pendidikan Islam, 03(01): 138159. DOI: https://dx.doi.org/10.31538/nzh.v3i1.522

Setiawan, Adib Rifqi. (2020, January 24). Pembelajaran Tematik Berorientasi Literasi Saintifik. Jurnal Basicedu: Journal of Elementary Education, 04(01): 71-80. URL: https://jbasic.org/index.php/basicedu/article/view/298

Setiawan, Adib Rifqi. (2019, December 30). Instrumen Penilaian Pembelajaran Fiqh Mu'āmalāt Berorientasi Literasi Finansial. Eklektik: Jurnal Pendidikan Ekonomi dan Kewirausahaan, 02(02): 258-272. DOI: http://dx.doi.org/10.24014/ekl.v2i2.8117

Setiawan, Adib Rifqi. (2019, December 20). Literasi Saintifik Berdasarkan Kecerdasan Majemuk dan Motivasi Belajar. Media Penelitian Pendidikan: Jurnal Penelitian dalam Bidang Pendidikan dan Pengajaran, 13(02): 126-137. DOI: http://dx.doi.org/10.26877/mpp.v13i2.4913

Setiawan, Adib Rifqi; Puspaningrum, Mita; \& Umam, Khoirul. (2019, December 06). Pembelajaran Fiqh Mu'āmalāt Berorientasi Literasi Finansial. Tarbawy: Indonesian Journal of Islamic Education, 06(02): 187-102. URL: https://ejournal.upi.edu/index.php/tarbawy/article/view/20887

Setiawan, Adib Rifqi. (2019, October 02). Efektivitas Pembelajaran Biologi Berorientasi Literasi Saintifik. Thabiea : Journal of Natural Science Teaching, 02 (02): 83-94. DOI: http://dx.doi.org/10.21043/thabiea.v2i2.5345

Setiawan, Adib Rifqi. (2019, September 30). Instrumen Penilaian untuk Pembelajaran Ekologi Berorientasi Literasi Saintifik. Assimilation: Indonesian Journal of Biology Education, 02(02): 42-46. DOI: https://dx.doi.org/10.17509/aijbe.v2i2.19250

Setiawan, Adib Rifqi; Mufassaroh, Arij Zulfi. (2019, June 28). Menyusun Soal Literasi Saintifik untuk Pembelajaran Biologi Topik Plantae dan Animalia. BIOSFER: Jurnal Biologi 
dan Pendidikan Biologi, 04(01): 33-40. URL:

http://dx.doi.org/10.23969/biosfer.v4i1.1484

Setiawan, Adib Rifqi. (2019, June 26). Peningkatan Literasi Saintifik melalui Pembelajaran Biologi Menggunakan Pendekatan Saintifik. Journal of Biology Education, 02(01): 223-235. URL: http://journal.stainkudus.ac.id/index.php/jbe/article/view/5278

Setiawan, Adib Rifqi; Utari, Setiya; Nugraha, Muhamad Gina. (2017, September 22). Mengonstruksi Rancangan Soal Domain Kompetensi Literasi Saintifik Siswa SMP Kelas VIII pada Topik Gerak Lurus. Wahana Pendidikan Fisika, 02(02): 44-48. URL: https://ejournal.upi.edu/index.php/WPF/article/view/8277/0

Setiawan, Adib Rifqi. (2020, April 20). Menyusun Instrumen Penilaian untuk Pembelajaran Ekologi Berorientasi Literasi Saintifik. Prosiding Seminar Nasional dan Workshop BiologiIPA dan Pembelajaran Ke-4 (SnoWBel IV): 241-9. ISBN : 978-602-470-170-3 \& eISBN : 978-602-470-171-0.

Setiawan, Adib Rifqi. (2020, February 18). Menyusun Instrumen Penilaian untuk Pembelajaran Topik Lingkungan Berorientasi Literasi Saintifik. Prosiding Seminar Nasional Fisika (SiNaFi) 2019: 15-21. URL: http://proceedings.upi.edu/index.php/sinafi/article/view/563

Setiawan, Adib Rifqi. (2020, January 17). Penggunaan Mabadi 'Asyroh dalam Pembelajaran Biologi untuk Meningkatkan Motivasi dan Hasil Belajar. Prosiding Seminar Nasional Biologi 2019 Inovasi Penelitian dan Pembelajaran Biologi III (IP2B III): 158-164. URL: http://semnasbiologi.conference.unesa.ac.id/ocs/index.php/semnasbio/IP2BIII/paper/v iewFile/11/21

Setiawan, Adib Rifqi. (2020, January 17). Upaya Meningkatkan Motivasi Belajar dalam Pembelajaran Ilmu Pengetahuan Alam (IPA) Melalui Bacaan Populer. Prosiding Seminar Nasional Biologi 2019 Inovasi Penelitian dan Pembelajaran Biologi III (IP2B III): 154-157. URL:

http://semnasbiologi.conference.unesa.ac.id/ocs/index.php/semnasbio/IP2BIII/paper/v iewFile/5/51

Setiawan, Adib Rifqi. (2020, January 17). Penerapan Pendekatan Saintifik dalam Pembelajaran Biologi sebagai Upaya Melatih Literasi Saintifik. Prosiding Seminar Nasional Biologi 2019 Inovasi Penelitian dan Pembelajaran Biologi III (IP2B III): 140-145. URL: http://semnasbiologi.conference.unesa.ac.id/ocs/index.php/semnasbio/IP2BIII/paper/v iewFile/6/19

Setiawan, Adib Rifqi. (2019, October 14). Penyusunan Program Pembelajaran Biologi Berorientasi Literasi Saintifik. Seminar Nasional Sains \& Entrepreneurship VI (SNSE VI): 255-18. URL: http://conference.upgris.ac.id/index.php/snse/article/view/255

Setiawan, Adib Rifqi. (2019, May 07). Penerapan Pendekatan Saintifik untuk Melatih Literasi Saintifik dalam Domain Kompetensi pada Topik Gerak Lurus di Sekolah Menengah Pertama. Prosiding Seminar Nasional Fisika (SiNaFi) 2018: 7-13. URL: http://proceedings.upi.edu/index.php/sinafi/article/view/355

Setiawan, Adib Rifqi. (2019, November 23). Profil Literasi Saintifik Berdasarkan Kecerdasan Majemuk dan Motivasi Belajar. Seminar Nasional Fisika V (SiNaFi 5.0), Universitas Pendidikan Indonesia (UPI). DOI: https://dx.doi.org/10.35542/osf.io/m7n95

Setiawan, Adib Rifqi. (2019, November 23). Menyusun Instrumen Penilaian untuk Pembelajaran Topik Lingkungan Berorientasi Literasi Saintifik. Seminar Nasional Fisika V (SiNaFi 5.0), Universitas Pendidikan Indonesia (UPI). DOI: https://dx.doi.org/10.35542/osf.io/sc6d2 
Setiawan, Adib Rifqi. (2019, November 23). Analisis Keabsahan dan Keandalan Science Motivation Questionnaire II (SMQ II) Versi Bahasa Indonesia. Seminar Nasional Fisika V (SiNaFi 5.0), Universitas Pendidikan Indonesia (UPI). DOI: https://doi.org/10.31237/osf.io/6zeph

Setiawan, Adib Rifqi. (2019, October 05). Menyusun Instrumen Penilaian untuk Pembelajaran Ekologi Berorientasi Literasi Saintifik. Seminar Nasional \& Workshop Biologi, IPA, dan Pembelajarannya ke-4 (SnoWBel IV), Universitas Negeri Malang (UM). DOI: https://dx.doi.org/10.13140/RG.2.2.21931.39206

Setiawan, Adib Rifqi. (2019, August 21). Penyusunan Program Pembelajaran Biologi Berorientasi Literasi Saintifik. Seminar Nasional Sains \& Entrepreneurship VI (SNSE VI), Universitas PGRI Semarang (UPGRIS). DOI: https://dx.doi.org/10.13140/RG.2.2.13716.86400

Setiawan, Adib Rifqi. (2019, March 23). Upaya Meningkatkan Motivasi Belajar dalam Pembelajaran Ilmu Pengetahuan Alam (IPA) Melalui Bacaan Populer. Seminar Nasional Biologi 2019 Inovasi Penelitian dan Pembelajaran Biologi III (IP2B III), Universitas Negeri Surabaya (UNESA). DOI: https://dx.doi.org/10.13140/RG.2.2.13087.71847

Setiawan, Adib Rifqi. (2019, March 23). Penerapan Pendekatan Saintifik dalam Pembelajaran Biologi sebagai Upaya Melatih Literasi Saintifik Siswa Sekolah Menengah. Seminar Nasional Biologi 2019 Inovasi Penelitian dan Pembelajaran Biologi III (IP2B III), Universitas Negeri Surabaya (UNESA). DOI: https://dx.doi.org/10.13140/RG.2.2.19798.60484

Setiawan, Adib Rifqi. (2019, March 23). Penggunaan Naḍom Mabādī 'Asyroh dalam Pembelajaran Biologi untuk Meningkatkan Motivasi dan Hasil Belajar. Seminar Nasional Biologi 2019 Inovasi Penelitian dan Pembelajaran Biologi III (IP2B III), Universitas Negeri Surabaya (UNESA). DOI: https://dx.doi.org/10.13140/RG.2.2.33220.37763

Setiawan, Adib Rifqi. (2018, November 24). Penerapan Pendekatan Saintifik untuk Melatih Literasi Saintifik dalam Domain Kompetensi pada Topik Gerak Lurus di Sekolah Menengah Pertama. Seminar Nasional Fisika ke-4 (SiNaFi IV), Universitas Pendidikan Indonesia (UPI). DOI: https://dx.doi.org/10.13140/RG.2.2.23154.04809

Setiawan, Adib Rifqi; Utari, Setiya; Nugraha, Muhamad Gina. (2016, December 17). Mengonstruksi Rancangan Soal Domain Kompetensi Literasi Saintifik Siswa SMP Kelas VIII pada Topik Gerak Lurus. Seminar Nasional Fisika ke-2 (SiNaFi II), Universitas Pendidikan Indonesia (UPI). DOI: https://dx.doi.org/10.13140/RG.2.2.31856.10246/1

Setiawan, Adib Rifqi. (2020, May 12). Introducing the Indonesian Education System. Thesis Commons. DOI: https://doi.org/10.31237/osf.io/ygt5c

Setiawan, A. R. (2020, May 7). Discovering the Fundamental Problem of Four Methods to Analyze Data. Thesis Commons. DOI: https://doi.org/10.31237/osf.io/h953y

Setiawan, Adib Rifqi. (2020, May 6). Menyibak Makna Karya Fadhilaturrahmi. LIS Scholarship Archive. DOI: https://doi.org/10.31229/osf.io/65y4z

Setiawan, Adib Rifqi. (2020, May 6). Discovering the Meaning of Fadhilaturrahmi's Work. Thesis Commons. DOI: https://doi.org/10.31237/osf.io/krf7z

Feldman, DarHalevy; \& Setiawan, Adib Rifqi. (2020, April 24). Education in Israel. Thesis Commons. DOI: https://doi.org/10.31237/osf.io/62shg

Setiawan, Adib Rifqi. (2020, April 18). Musyāfahah al-Qur'ān Melalui Media Elektronik. Thesis Commons. URL: https://thesiscommons.org/ntjp9/ 
Setiawan, Adib Rifqi. (2020, April 14). Jalāl al-Dīn ‘Abd al-Roḥmān ibn Abī Bakr al-Suyūṭ̂̄. SocArXiv. DOI: https://doi.org/10.31235/osf.io/5zf9v

Setiawan, Adib Rifqi. (2020, April 14). Commodification of the Sexuality in Kim Kardashian's Instagram Posts. SocArXiv. DOI: https://doi.org/10.31235/osf.io/kd6au

Velasufah, Whasfi; \& Setiawan, Adib Rifqi. (2020, April 13). Nilai Pesantren Sebagai Dasar Pendidikan Karakter. Thesis Commons. DOI: https://doi.org/10.31237/osf.io/hq6kz

Setiawan, Adib Rifqi. (2020, April 13). Commodification of the Sexuality in Kim Kardashian's Instagram Posts. Thesis Commons. URL: https://thesiscommons.org/mf7nw/

Setiawan, Adib Rifqi. (2020, April 13). مبادئ اللغة العربية. Thesis Commons. DOI: https://doi.org/10.31237/osf.io/2gvjf

Siayah, Syarofis; \& Setiawan, Adib Rifqi. (2020, April 13). A Brief Explanation of Science Education. EdArXiv. DOI: https://doi.org/10.35542/osf.io/2evn3

Siayah, Syarofis; \& Setiawan, Adib Rifqi. (2020, April 13). A Brief Explanation of Science Education. Thesis Commons. DOI: https://doi.org/10.31237/osf.io/wkvsn

Setiawan, Adib Rifqi; \& Ilmiyah, Surotul. (2020, April 13). Multiple Intelligences Based on Neuroscience. Thesis Commons. DOI: https://doi.org/10.31237/osf.io/e9fyu

Setiawan, Adib Rifqi; \& Ilmiyah, Surotul. (2020, April 13). Kecerdasan Majemuk Berdasarkan Neurosains. EdArXiv. DOI: https://doi.org/10.35542/osf.io/rj2fe

Setiawan, Adib Rifqi. (2020, April 9). Islamic Education in Southeast Asia. EdArXiv. DOI: https://doi.org/10.35542/osf.io/dnjqv

Setiawan, Adib Rifqi. (2020, April 9). Islamic Education in Southeast Asia. Thesis Commons. DOI: https://doi.org/10.31237/osf.io/e794d

Ilmiyah, Surotul; \& Setiawan, Adib Rifqi. (2020, April 7). Students' Worksheet for Distance Learning Based on Scientific Literacy in the Topic Coronavirus Disease 2019 (COVID-19). Thesis Commons. DOI: https://doi.org/10.31237/osf.io/fpg4j

Ilmiyah, Surotul; \& Setiawan, Adib Rifqi. (2020, April 7). Students' Worksheet for Distance Learning Based on Scientific Literacy in the Topic Coronavirus Disease 2019 (COVID-19). EdArXiv. DOI: https://doi.org/10.35542/osf.io/wyz5v

Setiawan, Adib Rifqi; \& Ilmiyah, Surotul. (2020, April 7). Lembar Kegiatan Siswa untuk Pembelajaran Jarak Jauh Berdasarkan Literasi Saintifik pada Topik Penyakit Coronavirus 2019 (COVID-19). EdArXiv. DOI: https://doi.org/10.35542/osf.io/h4632

Setiawan, Adib Rifqi. (2020, April 5). The Arrogant One. Thesis Commons. DOI: https://doi.org/10.31237/osf.io/8nmku

Setiawan, Adib Rifqi. (2020, April 4). Grace Natalie Louisa. SocArXiv. DOI: https://doi.org/10.31235/osf.io/zwf6g

Setiawan, Adib Rifqi. (2020, April 4). Grace Natalie Louisa. Thesis Commons. DOI: https://doi.org/10.31237/osf.io/u3mxv 
Setiawan, Adib Rifqi. (2020, April 3). Sharifah Halimah Alaydrus : a female preachers for our time. SocArXiv. DOI: https://doi.org/10.31235/osf.io/zb8qe

Setiawan, Adib Rifqi. (2020, April 2). Desain Pembelajaran untuk Membimbing Siswa Sekolah Dasar dalam Memperoleh Literasi Saintifik. EdArXiv. DOI: https://doi.org/10.35542/osf.io/u59f8

Setiawan, Adib Rifqi. (2020, April 2). What is the Best Way to Analyze Pre-Post Data?. EdArXiv. DOI: https://doi.org/10.35542/osf.io/h4e6q

Setiawan, Adib Rifqi. (2020, April 2). JUPE My Uncut Story. Open Science Framework (OSF). DOI: https://doi.org/10.31219/osf.io/qdxga

Setiawan, Adib Rifqi. (2020, April 1). Syarifah Halimah Alaydrus. Thesis Commons. DOI: https://doi.org/10.31237/osf.io/xbmcs

Setiawan, Adib Rifqi. (2020, April 1). Sharifah Halimah Alaydrus. Thesis Commons. DOI: https://doi.org/10.31237/osf.io/fp79c

Setiawan, Adib Rifqi. (2019, October 8). Biografi Clara Ng Perempuan Penulis Asal Indonesia. PsyArXiv. DOI: https://doi.org/10.31234/osf.io/yk8sx

Setiawan, Adib Rifqi. (2019, December 23). Contoh Langkah Pembelajaran Berorientasi Literasi Saintifik. santrimilenial.net. URL: https://santrimilenial.net/contoh-langkahpembelajaran-berorientasi-literasi-saintifik/

Setiawan, Adib Rifqi. (2019, June 14). Deasy Noviyanti, Perempuan Berbadan Defisit Lemak. qureta.com. URL: https://www.qureta.com/next/post/deasy-noviyanti-perempuanberbadan-defisit-lemak

Setiawan, Adib Rifqi. (2018, December 18). Irma Rahma Suwarma. qureta.com. URL: https://www.qureta.com/next/post/irma-rahma-suwarma

Setiawan, Adib Rifqi. (2018, October 05). Karen Armstrong. qureta.com. URL: https://www.qureta.com/next/post/karen-armstrong

Setiawan, Adib Rifqi. (2018, September 17). Lola Zieta Azelien. qureta.com. URL: https://www.qureta.com/next/post/lola-zieta-azelien

Setiawan, Adib Rifqi. (2018, July 16). Rustriningsih, Srikandi Tersisih. qureta.com. URL: https://www.qureta.com/next/post/rustriningsih-srikandi-tersisih

Setiawan, Adib Rifqi. (2018, July 03). Tangis Daniela Hantuchová. qureta.com. URL: https://www.qureta.com/next/post/tangis-daniela-hantuchova

Setiawan, Adib Rifqi. (2018, June 28). Dewi Perssik. qureta.com. URL: https://www.qureta.com/next/post/dewi-perssik

Setiawan, Adib Rifqi. (2018, June 27). Ice. qureta.com. URL: https://www.qureta.com/next/post/ice

Setiawan, Adib Rifqi. (2018, May 24). Fakhrun. qureta.com. URL: https://www.qureta.com/next/post/fakhrun

Setiawan, Adib Rifqi. (2018, April 10). Eny Rochmawati Octaviani: memberikan hiburan, menyuntikkan harapan. Majalah SANTRI, 8: 15-18. URL: https://issuu.com/majalahsantri/docs/majalah_santri_8/17

Setiawan, Adib Rifqi. (2018, April 10). Busana: pemantas raga, pelaras jiwa. Majalah SANTRI, 8: 2627. URL: https://issuu.com/majalahsantri/docs/majalah_santri_8/28 
Setiawan, Adib Rifqi. (2018, April 10). Rosa Amalia Iqony: paduan yakin diri dan rendah hati. Majalah SANTRI, 8: 46. URL:

https://issuu.com/majalahsantri/docs/majalah_santri_8/48

Setiawan, Adib Rifqi. (2018, March 25). Novi Kaka: Sahabat, Panutan, Pembimbing. qureta.com. URL: https://www.qureta.com/next/post/novi-kaka-sahabat-panutan-pembimbing

Setiawan, Adib Rifqi. (2018, March 21). Bidadari di Kesunyian itu Bernama Maria Sharapova. qureta.com. URL: https://www.qureta.com/next/post/bidadari-di-kesunyian-itubernama-maria-sharapova

Setiawan, Adib Rifqi. (2018, March 19). Airin Rachmi Diany, Lilin Penerang Masyarakat Urban. qureta.com. URL: https://www.qureta.com/next/post/airin-rachmi-diany-lilinpenerang-masyarakat-urban

Setiawan, Adib Rifqi. (2018, March 19). Kamu dalam Aku: A Brief Story of Park Bom. qureta.com. URL: https://www.qureta.com/next/post/kamu-dalam-aku-a-brief-story-of-parkbom

Setiawan, Adib Rifqi. (2018, March 19). Guru yang Menyapih: Catatan Perjalanan Pribadi Nong Darol Mahmada. qureta.com. URL: https://www.qureta.com/next/post/guru-yangmenyapih-catatan-perjalanan-pribadi-nong-darol-mahmada

Setiawan, Adib Rifqi. (2018, March 17). Maryam Musfiroh: An Educator for Our Time. qureta.com. URL: https://www.qureta.com/next/post/maryam-musfiroh-an-educator-for-ourtime

Setiawan, Adib Rifqi. (2018, March 15). Eny R. Octaviani. qureta.com. URL: https://www.qureta.com/next/post/eny-r-octaviani

Setiawan, Adib Rifqi. (2018, March 14). Surely You're Joking, Mrs. Ilmy!. qureta.com. URL: https://www.qureta.com/next/post/surely-you-re-joking-mrs-ilmy

Setiawan, Adib Rifqi. (2018, March 14). Meniti Ilmuwati. qureta.com. URL: https://www.qureta.com/next/post/meniti-ilmuwati

Setiawan, Adib Rifqi. (2018, March 12). Clara Ng. qureta.com. URL: https://www.qureta.com/next/post/clara-ng

Setiawan, Adib Rifqi. (2018, March 11). Kisah Kasih Ayah di Balik Mata Najwa. qureta.com. URL: https://www.qureta.com/next/post/kisah-kasih-ayah-di-balik-mata-najwa

Setiawan, Adib Rifqi. (2018, March 11). Rosa Amalia Iqony. qureta.com. URL: https://www.qureta.com/next/post/rosa-amalia-iqony

Setiawan, Adib Rifqi. (2018, March 10). Venice Min. qureta.com. URL: https://www.qureta.com/next/post/venice-min

Setiawan, Adib Rifqi. (2018, March 09). Ketika YoonA Menyaksikan Real Madrid Menghempaskan PSG. qureta.com. URL: https://www.qureta.com/next/post/ketika-yoonamenyaksikan-real-madrid-menghempaskan-psg

Setiawan, Adib Rifqi. (2018, March 09). Kepedulian Airin Rachmi Diany pada Pendidikan. qureta.com. URL: https://www.qureta.com/next/post/kepedulian-airin-rachmidiany-pada-pendidikan

Setiawan, Adib Rifqi. (2018, March 09). Laila Fariha Zein (a.k.a. Uus atau Febi). qureta.com. URL: https://www.qureta.com/next/post/laila-fariha-zein-febi

Setiawan, Adib Rifqi. (2018, March 09). Pantat Perekat Umat. qureta.com. URL: https://www.qureta.com/next/post/pantat-perekat-umat 
Setiawan, Adib Rifqi. (2018, March 09). Sisi Religi Grace Natalie. qureta.com. URL: https://www.qureta.com/next/post/sisi-religi-grace-natalie

Setiawan, Adib Rifqi. (2018, March 09). Asal Usul Nama Via Vallen. qureta.com. URL: https://www.qureta.com/next/post/asal-usul-nama-via-vallen

Setiawan, Adib Rifqi. (2018, March 07). Mengenal Oza Kioza. qureta.com. URL: https://www.qureta.com/next/post/mengenal-oza-kioza

Setiawan, Adib Rifqi. (2018, March 06). Menyoal Vokal Duo Serigala. qureta.com. URL: https://www.qureta.com/next/post/menyoal-vokal-duo-serigala

Setiawan, Adib Rifqi. (2018, March 06). Breast Capital. qureta.com. URL: https://www.qureta.com/next/post/breast-capital

Amatullah; \& Setiawan, Adib Rifqi. (2017, October 10). Nadirsyah Hosen: berkarya sebagai diaspora. Majalah SANTRI, 7: 56-59. URL: https://issuu.com/majalahsantri/docs/santri_edisi_7/58

Setiawan, Adib Rifqi. (2017, June 03). Dari Yuli Hingga Julia. qureta.com. URL: https://www.qureta.com/next/post/dari-yuli-hingga-julia-2

Setiawan, Adib Rifqi. (2017, June 02). Aisha. qureta.com. URL: https://www.qureta.com/next/post/aisha-humaira

Setiawan, Adib Rifqi. (2015, November 10). Kehidupan Asmara Hawking: raga lumpuh, jiwa masih bisa tersentuh. fisikanet.lipi.go.id. URL:

http://www.fisikanet.lipi.go.id/utama.cgi?artikel\&1447145876\&2

Setiawan, Adib Rifqi. (2015, November 07). Dibalik Sampul Buku A Brief History of Time, agar pengetahuan tak hanya dinikmati ilmuwan. fisikanet.lipi.go.id. URL: http://www.fisikanet.lipi.go.id/utama.cgi?artikel\&1446855103\&2

Setiawan, Adib Rifqi. (2015, November 03). Dibalik Nama Besar Albert Einstein: Dari Politik, Asmara, hingga Matematika. fisikanet.lipi.go.id. URL: http://www.fisikanet.lipi.go.id/utama.cgi?artikel\&1446556354\&2

Setiawan, Adib Rifqi. (2015, October 31). Kurir Mikroskopis Alam Semesta bukan debu biasa. fisikanet.lipi.go.id. URL: http://www.fisikanet.lipi.go.id/utama.cgi?artikel\&1446304060\&2

Setiawan, Adib Rifqi. (2015, October 10). 10 Kejutan Subatomik. fisikanet.lipi.go.id. URL: http://www.fisikanet.lipi.go.id/utama.cgi?artikel\&1444577286\&3 


\section{APPENDIX A}

Table 2. TeG Readiness: Process of Enactment for Trans-formational E-Government Success

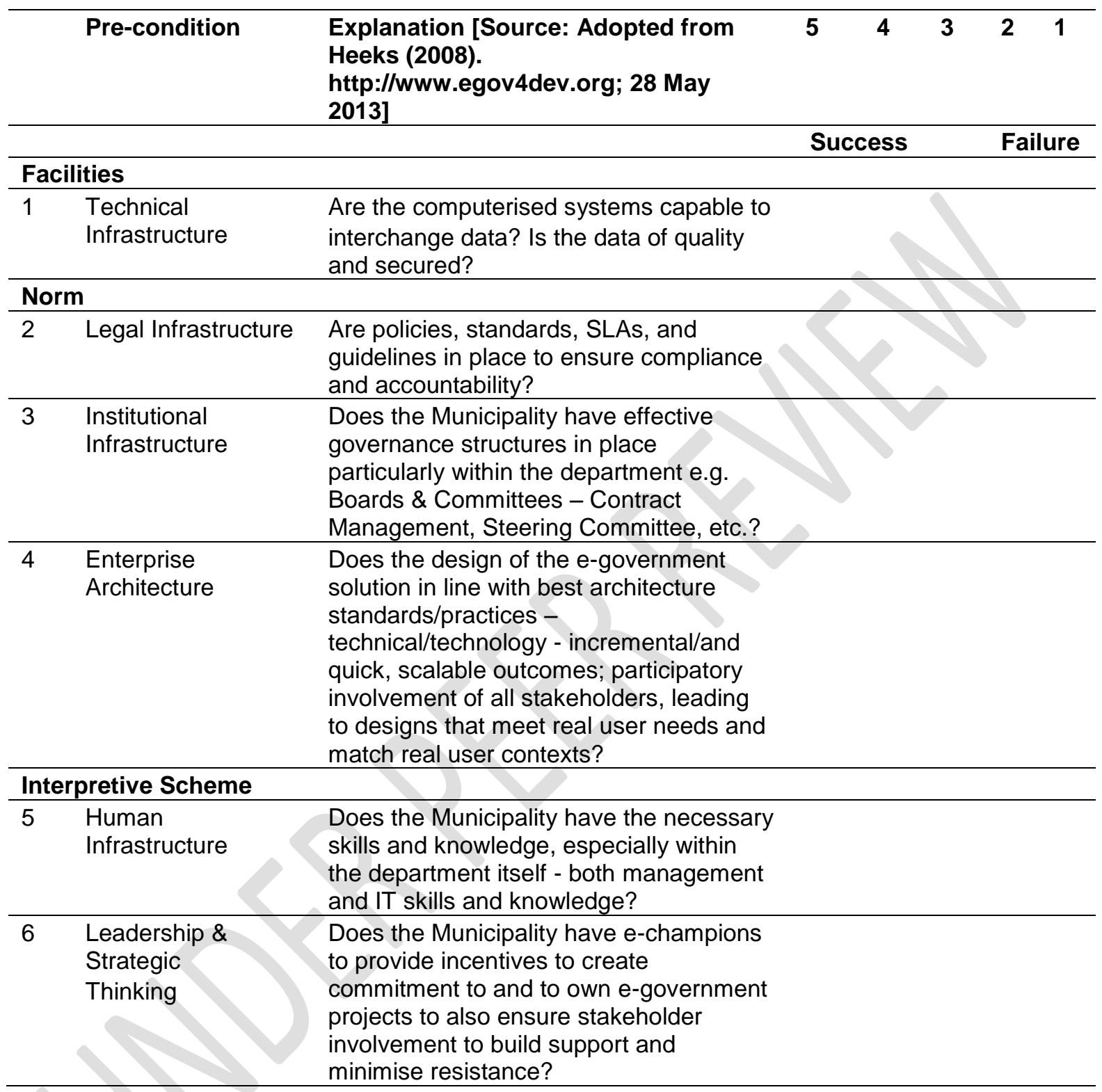




\section{APPENDIX B}

Table 3. Participated Municipalities and Metros in South Africa

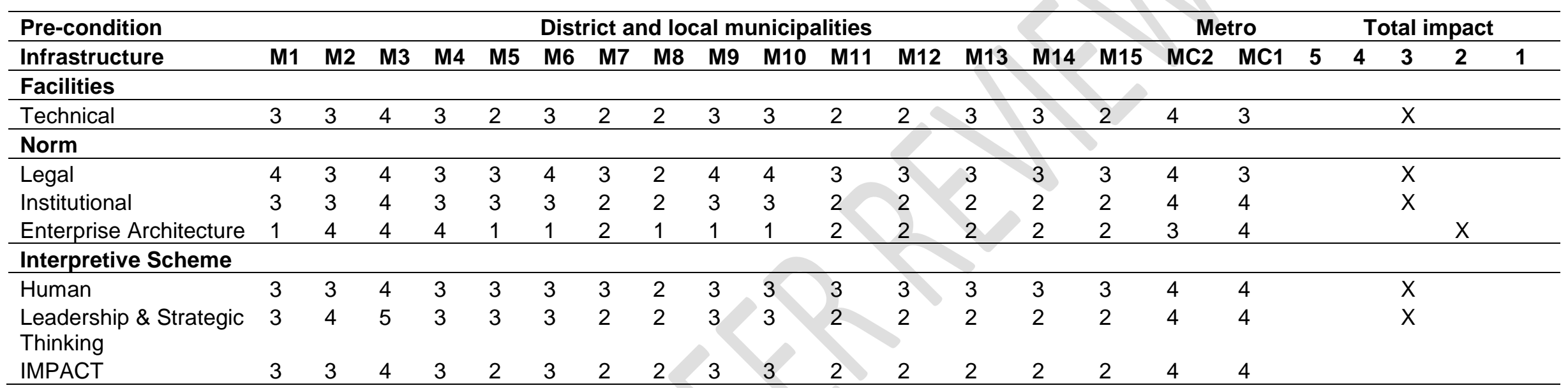




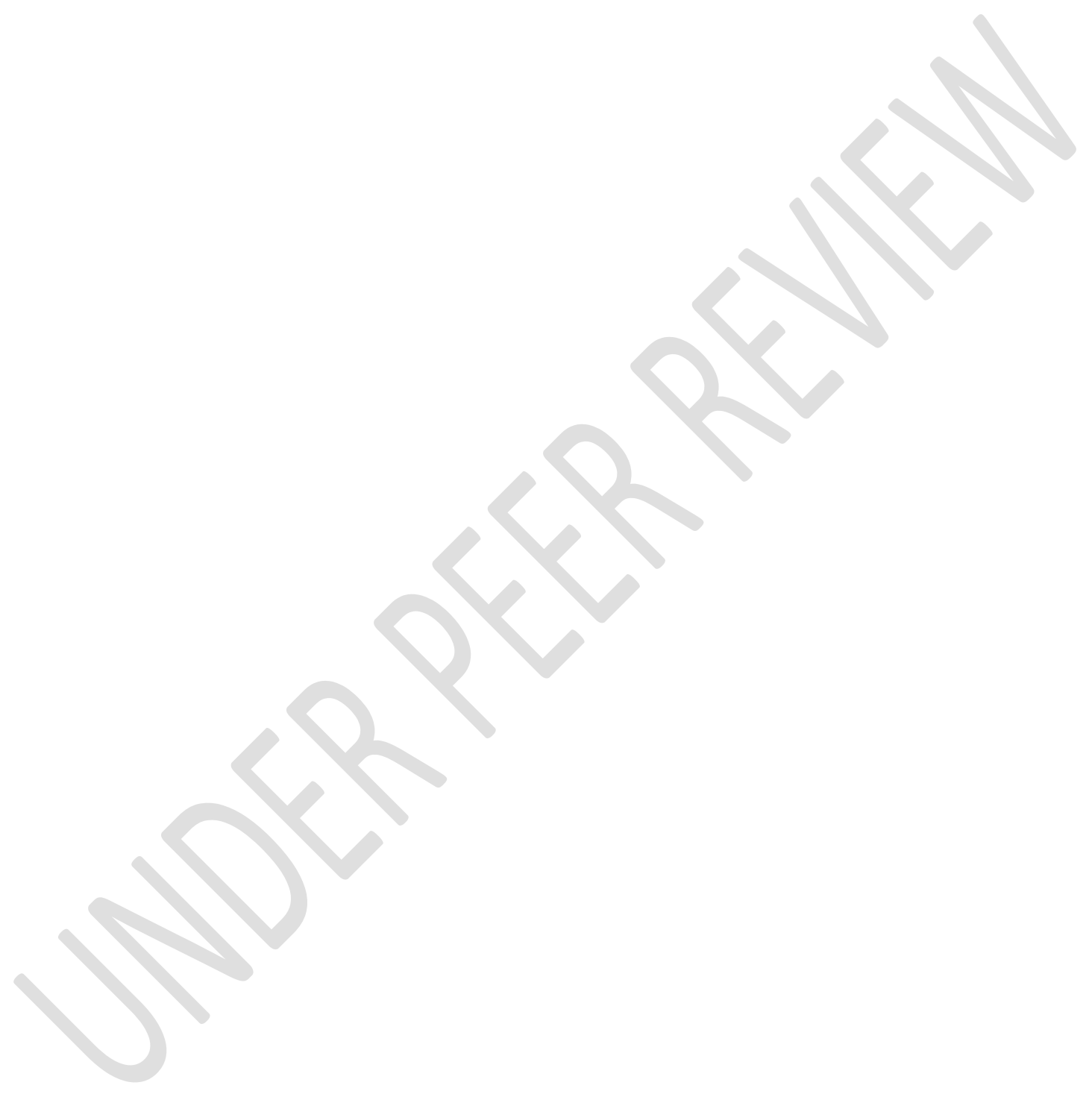

